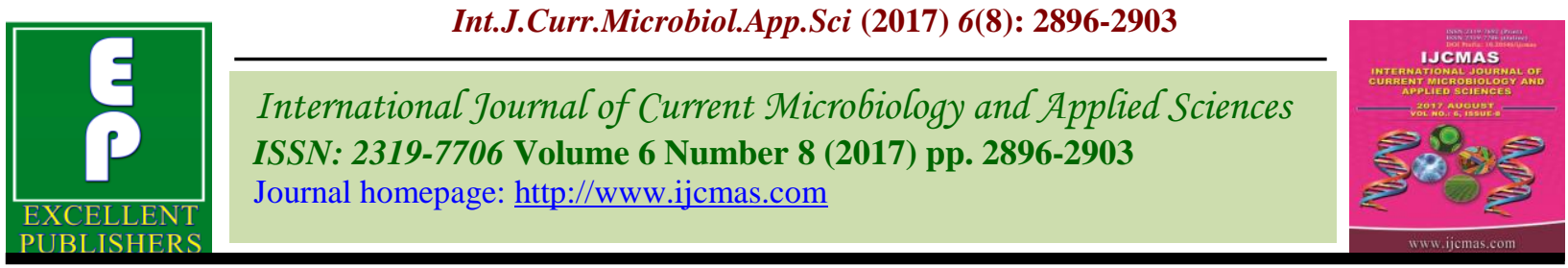

Original Research Article

https://doi.org/10.20546/ijcmas.2017.608.346

\title{
Seed Size Correlates with Germination Traits in Terminalia arjuna Genotypes
}

\author{
Hemant Kumar", S.B. Lal, A.M. Wani, Rajiv Umrao, \\ Neelam Khare and Neeta Shweta Kerketta
}

\begin{abstract}
College of Forestry, Sam Higginbottom University of Agriculture, Technology and Sciences, Allahabad 211007, U.P., India

*Corresponding author
\end{abstract}

\section{A B S T R A C T}

Keywords

Terminalia arjuna, Seed size correlation, Germination parameters, Genotypes.

Article Info

Accepted:

23 June 2017

Available Online:

10 August 2017
Seed size emerged as a governing characteristic for germination parameters and seedling establishment owing to best evolutionary traits of plant which impart major contribution in genetic diversity. Large size increased germination rate and seedling survival, accelerated germination timing, and enhanced seedling growth. Present experiment is carried out to assess the seed size correlates with germination characteristics in Terminalia arjuna. The findings suggest that the seedling vigour is a fixed positive function of seed size needs to be reconsidered. Germination of large seeds recorded slightly higher than small size and ranges from 68.33 to $43.33 \%$. Mean daily germination value ranged between 1.81 to 2.85 , Peak value of germination ranged between 3.15 to 4.59 , Germination value ranged between 5.79to 13.67 and germination speed ranged between 3.71 to 5.88 . The existence of conflicting selection might explain the occurrence of an optimal seed size in some plant species without invoking a seed number-size trade-off. Hence, it is recommended to use only medium and large size seeds for growing, because they do result in higher germination behavior and seedling establishment.

\section{Introduction}

The most successful tree improvement programme is that where proper seed sources were used. The loss from using the wrong sources can be great and even disastrous. Size of seed is best evolutionary traits of plant which impart major contribution in genetic diversity (Aniszewski et al., 2001). The good quality seeds are those which have genetic purity, physical purity, health standards, germiniability and moisture percentage in accordance with the minimum seed certification standards. Provenance-dependent variations in seed size are also recorded
(Ellison, 2001; Dlamini, 2011). Successful establishment of seedlings depends on seed size and contributes competition among the plants (Zhang, 1998), however fruit pulp adhering to the seeds has been found to have an inhibitory effect on germination in this species. Comparatively fewer large and many small seeds produced by most of the plant species (Stevenson et al., 2005). Smaller seeds with sufficient number are useful for dispersal over wide areas. On the other hand, the energy potential of large seeds is considered to emerge better in most of the 
habitats (Stevenson et al., 2005). Large seeds show better germination parameter and establishment potential of seedlings as compared with medium and small seeds (Murali, 1997; Negi and Todaria, 1997; Khan and Shankar, 2001; Mwase and Mvula, 2011). Consideration of seed traits may be a useful aspect for propagation and conservation of valuable plants (Khurana and Singh, 2001). Terminalia arjunais commonly propagated through seeds hence the seed size trait in seedling emergence has been highly acknowledged for the development of quality planting stock.

Terminalia arjuna L. (Arjun, Koha, Kahu and Arjan in Hindi; Arjuna, Dhanvi, Indradruma, Kakubha, Karvirak and Nadisarjja in Sanskrit; Arjhan in Bengali; Sahjoin Oriya; Sadada and Sadado in Gujarati; Sadurain Marathi; Vellamatta in Tamil and Yerra Maddiin Telugu.), Family: Combretaceae) is used as fodder, fuel wood and in the variety of herbal medicines. Terminalia arjuna is a fast growing tree that has a high potential of biomass production and ability to grow on marginal and degraded lands. It has immense economic importance in various industries viz., pharmaceutical, timber, paper, soap, match, food, fodder and fuel. The dried stem bark of Terminalia arjuna has been used widely as a drug in Ayurvedic medicine as a cardiotonic, for injury or wound, blood disorders, obesity, urinary disorders and ulcer or wound. The tree species is usually used in agro and social forestry for reclamation of degraded lands. For instance saline and alkaline soils, deep ravines and mine spoil. The growing interest in the bark of Terminalia arjuna and the realization of the need for raising high biomass and bark yielding plantations has led to the search for technologies for its growth and profitable production. Owing to the multipurpose value of $T$. arjuna, the need for its adequate regeneration is important (Rathore et al., 2008). Collection of seeds at the appropriate time, consideration of seed size and presowing treatments have been found to be useful for improving germination in some species of Terminalia (Agboola et al., 1993; Amri, 2010). Selection of superior genotypes and seeds size may be useful for efficient germination and establishment of seedlings. Effect of seed size on seedling emergence and growth parameter in $T$. arjuna under nursery conditions is reported in this research paper.

\section{Materials and Methods}

The investigation was carried out in Research Farm of College of Forestry SHUAT, Allahabad, Uttar Pradesh during 2014-15 to find the association between seed size and germination parameter The experimental site at elevation of $98 \mathrm{~m}$ above sea level at $28.87^{\circ}$ $\mathrm{N}$ latitude and $81.15^{\circ} \mathrm{E}$ longitude. The characteristics of the soil are sandy loam in order to Inceptisol soil. The research area has a sub-tropical climate with extremes of summer and winter. During the summer season, the temperature reaches upto $46-48^{\circ} \mathrm{C}$, while during winter season, especially in the month of Nov. and Jan. temperature drops down to as low as $1-2^{\circ} \mathrm{C}$. During winter, frost and during summer, hot scorching wind are common features. The average rainfall in this area is around $882 \mathrm{~mm}$, during the monsoon i.e. June to Sept, with a few occasional light showers and drizzles are seen in the winter also.

More than 3000 mature fruits were collected from different parts of the crown of an individual plus tree selected from 30 different locations of state Uttar Pradesh (Table 1 and Figure 1). The fruits were cleaned and stored in muslin bags at ambient conditions before sowing. All lots were dried under similar temperature and humidity to reach constant weight. Observations on fruit characters were taken of plus tree and replication wise. Dark brown, matured (ripened) seeds of $T$. arjuna, were collected from different parts of Uttar 
Pradesh in the month of March 2014. For taking observations on fruit characters, 30 fruits / tree was collected randomly from different parts of the tree and average of 30 fruits measurement was recorded for fruit length, width and fruit weight for sorting and seedling establishment in the nursery. The seed sample comprised large and small seeds, which were separated out for experimental purpose. All the seeds were weighed (digital electronic balance, Mx 7000 series) and the length and diameter (Digital Vernier calipers) of the seeds were also measured. Air-dried seeds of each category were given pregermination treatments of 2 days of water soaking and sown in triplicate (each replicate containing 20 seeds) under nursery conditions (in black $100 \times 152 \mathrm{~mm}$ polybags (containing soil, farmyard manure [FYM], and sand in a ratio of $1: 1: 1$ ) at a depth of $20 \mathrm{~mm}$ in the first week of July.

The seeds were regularly monitored in terms of the onset of germination and number of seedlings established, over a period of 12 months. Values obtained for weights, lengths and diameters of all seeds in each replicate were averaged. The number of days required for onset of germination, seedling emergence, mean time for the onset of germination (MGT) and percent seedling emergence in each replicate per seed-size category were averaged. Single factor-analysis of variance (ANOVA) for germination traits in relation to seed size was calculated.

The data were subjected to statistical analysis appropriate to the design and significance of different sources of variations was tested by Fisher's and Snedecor's F-test at probability level of 0.05 (Chandel, 1984) to obtain information on the mean performance and to assess the correlation of seed characteristics and total emergence of seedlings (\%). Standard errors (SE) for the values obtained were calculated. Mean germination time was calculated by slightly modifying the formula suggested by Butola and Badola (2004).

\section{Results and Discussion}

Large size increased germination rate and seedling survival, accelerated germination timing, and enhanced seedling growth. Germination of large seeds recorded slightly higher than small size and ranges from 68.33 to $43.33 \%$. Mean daily germination value ranged between 1.81 to 2.85 , Peak value of germination ranged between 3.15 to 4.59 , Germination value ranged between 5.79to 13.67and germination speed ranged between 3.71 to 5.88. Most of the germination parameters of large, medium and small seeds have slight differences and varied nonsignificantly. Mean Germination Time (MGT) for the seedlings from large, medium and small seeds was comparable. Seed characteristics such as weight, length and diameter were positively correlated with the germination parameter of seeds (Table 2 and Fig. 2). Perusal of data represented in table 2, a greater number of seedlings germination from the large seeds followed by medium while relatively lower seedlings germination were established from small seeds. Significant variations were observed among the numbers of seedlings established from different sized. Seed size emerged as a governing characteristic for germination and seedling establishment in $T$. arjuna. Higher germination have been reported for the large seeds compared with medium and small seeds laboratory conditions (Negi and Todaria, 1997), similar to the trend currently observed under nursery conditions. However, different species of Terminalia may exhibit similar, or diverse, germination responses in relation to seed size and pre-treatments (Agboola et al., 1993; Murali, 1997; Schiotz et al., 2006; Shivanna et al., 2007; Likoswe et al., 2008; Amri, 2010). 
Table.1 Details of morphological observations of thirty plus trees of Terminalia arjuna collected from different locations $\left(\mathrm{S}_{1}-\mathrm{S}_{30}\right)$

\begin{tabular}{|c|c|c|c|c|c|c|c|c|}
\hline $\begin{array}{l}\text { Seed } \\
\text { source }\end{array}$ & Location & Latitude & Longitude & $\begin{array}{c}\text { Age of } \\
\text { tree } \\
\text { (years) }\end{array}$ & $\begin{array}{c}\text { Tree } \\
\text { heigh } \\
\mathrm{t}(\mathrm{m})\end{array}$ & $\begin{array}{l}\text { Tree } \\
\text { girth } \\
(\mathrm{cm})\end{array}$ & $\begin{array}{l}\text { Fruit } \\
\text { length } \\
(\mathrm{mm})\end{array}$ & $\begin{array}{l}\text { Fruit } \\
\text { width } \\
(\mathrm{mm}) \\
\end{array}$ \\
\hline $\mathrm{S}_{1}$ & Chamanbagh, Fatehpur & $25^{0} 94^{\prime} \mathrm{N}$ & $80^{0} 80^{\prime} \mathrm{E}$ & $10-12$ & 14.00 & 72.10 & 31.07 & 22.94 \\
\hline $\mathrm{S}_{2}$ & Allen forest, Kanpur & $26^{0} 50 \mathrm{~N}$ & $80^{0} 30^{\prime} \mathrm{E}$ & $12-18$ & 16.00 & 85.90 & 27.04 & 20.27 \\
\hline $\mathrm{S}_{3}$ & Cant, Varanasi & $25^{0} 33^{\prime} \mathrm{N}$ & $82^{0} 98^{\prime} \mathrm{E}$ & $12-15$ & 14.00 & 73.40 & 42.04 & 31.14 \\
\hline $\mathrm{S}_{4}$ & KendriyaVidyalaya, Basti & $26^{0} 80^{\prime} \mathrm{N}$ & $82^{0} 70^{\prime} \mathrm{E}$ & $10-15$ & 12.00 & 78.60 & 41.90 & 31.24 \\
\hline $\mathrm{S}_{5}$ & Baghauchghat, Deoria & $26.57^{\prime} \mathrm{N}$ & $84.00^{\prime} \mathrm{E}$ & $10-15$ & 16.00 & 84.10 & 39.57 & 29.14 \\
\hline $\mathrm{S}_{6}$ & Fazilnagar, Kushinagar, & $26^{0} 68^{\prime} \mathrm{N}$ & $84^{0} 05^{\prime} \mathrm{E}$ & $15-17$ & 12.00 & 78.10 & 39.77 & 29.10 \\
\hline $\mathrm{S}_{7}$ & $\begin{array}{l}\text { Kartaniaghat Range } \\
\text { Office, Bahraich }\end{array}$ & $28^{0} 33^{\prime} \mathrm{N}$ & $81^{0} 13^{\prime} \mathrm{E}$ & $12-16$ & 14.00 & 114.20 & 38.77 & 29.04 \\
\hline $\mathrm{S}_{8}$ & $\begin{array}{l}\text { Irrigation Department, } \\
\text { Gonda }\end{array}$ & $27^{0} 13^{\prime} \mathrm{N}$ & $81^{0} 95^{\prime} \mathrm{E}$ & $15-17$ & 12.00 & 74.30 & 29.17 & 21.70 \\
\hline $\mathrm{S}_{9}$ & $\begin{array}{l}\text { KawwaBagh Colony, } \\
\text { Gorakhpur }\end{array}$ & $26^{0} 75^{\prime} \mathrm{N}$ & $83^{0} 38^{\prime} \mathrm{E}$ & $11-14$ & 10.00 & 73.10 & 31.77 & 23.77 \\
\hline $\mathrm{S}_{10}$ & Gandhi Udhyan, Bareilly & $28^{0} 34^{\prime} \mathrm{N}$ & $79^{0} 43^{\prime} \mathrm{E}$ & $10-13$ & 15.00 & 77.20 & 25.67 & 19.24 \\
\hline $\mathrm{S}_{11}$ & $\begin{array}{l}\text { Railway station road, } \\
\text { Sirathu, Kaushambhi }\end{array}$ & $25^{0} 65^{\prime} \mathrm{N}$ & $81^{0} 32^{\prime} \mathrm{E}$ & $12-14$ & 14.00 & 87.30 & 38.10 & 28.34 \\
\hline $\mathrm{S}_{12}$ & $\begin{array}{l}\text { Sitasamahitsthalsitamarhi, } \\
\text { Bhadohi }\end{array}$ & $25^{0} 27^{\prime} \mathrm{N}$ & $82^{0} 26^{\prime} \mathrm{E}$ & $11-12$ & 14.00 & 112.10 & 32.87 & 24.53 \\
\hline $\mathrm{S}_{13}$ & Kukrail, Lucknow & $26^{0} 91^{\prime} \mathrm{N}$ & $80^{0} 98^{\prime} \mathrm{E}$ & $11-16$ & 14.00 & 114.70 & 32.57 & 24.34 \\
\hline $\mathrm{S}_{14}$ & $\begin{array}{l}\text { U P Forest Corporation } \\
\text { Lakhimpur, }\end{array}$ & $27^{0} 94^{\prime} \mathrm{N}$ & $80^{0} 79^{\prime} \mathrm{E}$ & $14-15$ & 11.00 & 82.20 & 31.27 & 23.27 \\
\hline $\mathrm{S}_{15}$ & $\begin{array}{l}\text { Company Garden } \\
\text { Beribagh, Saharanpur, }\end{array}$ & $29^{0} 97^{\prime} \mathrm{N}$ & $77^{0} 56^{\prime} \mathrm{E}$ & $12-16$ & 11.00 & 102.30 & 23.84 & 18.24 \\
\hline $\mathrm{S}_{16}$ & SHUATS, Allahabad & $25^{0} 41^{\prime} \mathrm{N}$ & $81^{0} 85^{\prime} \mathrm{E}$ & $15-18$ & 17.00 & 71.80 & 23.94 & 17.97 \\
\hline $\mathrm{S}_{17}$ & Shahjahanpur road, Sitapur & $27^{0} 58^{\prime} \mathrm{N}$ & $80^{\circ} 65^{\prime} \mathrm{E}$ & $11-15$ & 12.00 & 85.30 & 22.90 & 17.17 \\
\hline $\mathrm{S}_{18}$ & $\begin{array}{l}\text { V.B.S.Purvanchal } \\
\text { University, Jaunpur }\end{array}$ & $25^{\circ} 83^{\prime} \mathrm{N}$ & $82^{0} 68^{\prime} \mathrm{E}$ & $12-15$ & 11.00 & 54.80 & 20.34 & 15.44 \\
\hline $\mathrm{S}_{19}$ & Railway ground, Mau & $25^{0} 94^{\prime} \mathrm{N}$ & $83^{0} 56^{\prime} \mathrm{E}$ & $12-17$ & 10.00 & 75.70 & 21.10 & 15.94 \\
\hline $\mathrm{S}_{20}$ & Obra forest, Sonbhadra & $24^{0} 46^{\prime} \mathrm{N}$ & $82^{0} 99^{\prime} \mathrm{E}$ & $12-16$ & 11.00 & 68.30 & 25.37 & 18.97 \\
\hline $\mathrm{S}_{21}$ & Malka Park, Bulandshahar & $28^{0} 41^{\prime} \mathrm{N}$ & $77^{0} 85^{\prime} \mathrm{E}$ & $15-18$ & 11.00 & 98.10 & 25.20 & 18.77 \\
\hline $\mathrm{S}_{22}$ & Deer park, Moradabad & $28^{0} 82^{\prime} \mathrm{N}$ & $78^{0} 81^{\prime} \mathrm{E}$ & $10-14$ & 10.00 & 62.80 & 29.04 & 21.60 \\
\hline $\mathrm{S}_{23}$ & $\begin{array}{l}\text { Company Garden, } \\
\text { Pratapgarh }\end{array}$ & $25^{\circ} 92^{\prime} \mathrm{N}$ & $82^{0} 07^{\prime} \mathrm{E}$ & $12-14$ & 11.00 & 68.80 & 25.77 & 19.40 \\
\hline $\mathrm{S}_{24}$ & Gandhi Park, Meerut Cantt & $29^{0} 01^{\prime} \mathrm{N}$ & $77^{0} 70^{\prime} \mathrm{E}$ & $11-15$ & 14.00 & 111.10 & 25.37 & 18.93 \\
\hline $\mathrm{S}_{25}$ & $\begin{array}{l}\text { Indira Gandhi Vanaspati } \\
\text { Udyan, Raibareily }\end{array}$ & $26^{0} 20^{\prime} \mathrm{N}$ & $81^{0} 25^{\prime} \mathrm{E}$ & $12-15$ & 11.00 & 102.20 & 33.57 & 24.97 \\
\hline $\mathrm{S}_{26}$ & Barkachha, Mirzapur & $25^{0} 05^{\prime} \mathrm{N}$ & $82^{0} 60^{\prime} \mathrm{E}$ & $12-15$ & 10.00 & 96.30 & 14.80 & 12.48 \\
\hline $\mathrm{S}_{27}$ & Lohiya park, Kanauj & $27^{0} 01^{\prime} \mathrm{N}$ & $79^{0} 92^{\prime} \mathrm{E}$ & $11-16$ & 11.00 & 66.20 & 22.33 & 16.60 \\
\hline $\mathrm{S}_{28}$ & Katai Mill, Banda & $25^{0} 51^{\prime} \mathrm{N}$ & $80^{0} 34^{\prime} \mathrm{E}$ & $11-16$ & 10.00 & 61.70 & 23.44 & 17.60 \\
\hline $\mathrm{S}_{29}$ & $\begin{array}{l}\text { Dr. BhimraoAmbedkar } \\
\text { Park, Unnao }\end{array}$ & $26^{0} 55^{\prime} \mathrm{N}$ & $80^{\circ} 48^{\prime} \mathrm{E}$ & $12-16$ & 10.00 & 62.60 & 23.03 & 17.24 \\
\hline $\mathrm{S}_{30}$ & AarogyaDhaamChitrakoot & $25^{0} 16^{\prime} \mathrm{N}$ & $80^{0} 86^{\prime} \mathrm{E}$ & $11-16$ & 14.00 & 90.20 & 24.94 & 18.60 \\
\hline
\end{tabular}


Int.J.Curr.Microbiol.App.Sci (2017) 6(8): 2896-2903

Table.2 Seed size correlates with seedling emergence in Terminalia arjuna genotypes

\begin{tabular}{|c|c|c|c|c|c|c|c|c|}
\hline $\begin{array}{l}\text { Seed source } \\
\text { (Genotypes) }\end{array}$ & $\begin{array}{l}\text { Length } \\
(\mathrm{mm})\end{array}$ & $\begin{array}{l}\text { Width } \\
(\mathrm{mm})\end{array}$ & $\begin{array}{l}\text { 100-Fruit } \\
\text { weight (g) }\end{array}$ & $\begin{array}{c}\text { Germ } \\
(\%)\end{array}$ & MDG & $\begin{array}{l}\text { Peak } \\
\text { Value }\end{array}$ & $\begin{array}{l}\text { Germ } \\
\text { Value }\end{array}$ & $\begin{array}{l}\text { Germ } \\
\text { Speed }\end{array}$ \\
\hline $\mathrm{S}_{1}$ & 30.40 & 22.07 & 234.13 & 46.67 & 1.94 & 3.28 & 6.39 & 4.11 \\
\hline $\mathrm{S}_{2}$ & 26.47 & 19.53 & 259.00 & 55.00 & 2.29 & 3.76 & 8.79 & 4.81 \\
\hline $\mathrm{S}_{3}$ & 41.20 & 30.00 & 310.40 & 65.00 & 2.71 & 4.25 & 11.58 & 5.38 \\
\hline $\mathrm{S}_{4}$ & 41.00 & 30.00 & 321.87 & 60.00 & 2.50 & 3.93 & 9.82 & 4.89 \\
\hline $\mathrm{S}_{5}$ & 33.13 & 24.13 & 412.00 & 58.33 & 2.43 & 3.83 & 9.33 & 5.01 \\
\hline $\mathrm{S}_{6}$ & 44.53 & 32.47 & 490.67 & 56.67 & 2.36 & 3.78 & 9.12 & 4.83 \\
\hline $\mathrm{S}_{7}$ & 38.00 & 27.80 & 238.07 & 66.67 & 2.78 & 4.33 & 12.10 & 5.88 \\
\hline $\mathrm{S}_{8}$ & 28.60 & 20.87 & 262.13 & 45.00 & 1.88 & 3.15 & 5.90 & 4.06 \\
\hline $\mathrm{S}_{9}$ & 31.13 & 22.80 & 304.27 & 48.33 & 2.02 & 3.21 & 6.46 & 3.71 \\
\hline$S_{10}$ & 25.13 & 18.47 & 277.20 & 50.00 & 2.09 & 3.60 & 7.82 & 4.27 \\
\hline$S_{11}$ & 37.40 & 27.27 & 313.00 & 48.33 & 2.02 & 3.46 & 7.08 & 4.43 \\
\hline $\mathrm{S}_{12}$ & 32.13 & 23.53 & 313.80 & 61.67 & 2.57 & 4.02 & 10.53 & 5.36 \\
\hline$S_{13}$ & 31.80 & 23.27 & 216.40 & 50.00 & 2.08 & 3.59 & 7.79 & 4.32 \\
\hline $\mathrm{S}_{14}$ & 30.60 & 22.27 & 202.27 & 50.00 & 2.08 & 3.67 & 7.87 & 4.39 \\
\hline$S_{15}$ & 23.40 & 17.20 & 203.67 & 55.00 & 2.29 & 3.45 & 8.02 & 4.92 \\
\hline$S_{16}$ & 23.40 & 17.27 & 213.00 & 50.00 & 2.08 & 3.26 & 6.80 & 4.45 \\
\hline $\mathrm{S}_{17}$ & 22.60 & 16.53 & 208.73 & 65.00 & 2.71 & 4.04 & 11.19 & 5.58 \\
\hline $\mathrm{S}_{18}$ & 20.00 & 15.00 & 231.67 & 60.00 & 2.50 & 3.93 & 10.18 & 5.15 \\
\hline $\mathrm{S}_{19}$ & 20.80 & 15.27 & 154.00 & 58.33 & 2.43 & 3.87 & 9.59 & 5.04 \\
\hline$S_{20}$ & 24.87 & 18.20 & 163.07 & 58.33 & 2.43 & 3.73 & 9.17 & 5.20 \\
\hline$S_{21}$ & 24.67 & 18.00 & 161.87 & 68.33 & 2.85 & 4.59 & 13.67 & 5.82 \\
\hline $\mathrm{S}_{22}$ & 28.40 & 20.73 & 169.47 & 43.33 & 1.81 & 3.21 & 5.79 & 3.71 \\
\hline $\mathrm{S}_{23}$ & 25.27 & 18.53 & 177.27 & 61.67 & 2.57 & 4.12 & 11.01 & 5.52 \\
\hline $\mathrm{S}_{24}$ & 24.87 & 18.33 & 184.27 & 50.00 & 2.08 & 3.29 & 6.87 & 4.15 \\
\hline $\mathrm{S}_{25}$ & 32.87 & 23.93 & 113.27 & 56.67 & 2.36 & 3.60 & 8.56 & 4.99 \\
\hline$S_{26}$ & 14.87 & 10.88 & 114.07 & 48.33 & 2.02 & 3.29 & 6.65 & 3.96 \\
\hline $\mathrm{S}_{27}$ & 21.93 & 16.13 & 122.93 & 56.67 & 2.36 & 3.57 & 8.46 & 4.62 \\
\hline $\mathrm{S}_{28}$ & 23.07 & 17.07 & 125.40 & 53.33 & 2.22 & 3.47 & 7.77 & 4.62 \\
\hline $\mathrm{S}_{29}$ & 22.53 & 16.47 & 138.27 & 51.67 & 2.15 & 3.38 & 7.40 & 4.28 \\
\hline$S_{30}$ & 24.40 & 17.80 & 175.27 & 51.67 & 2.15 & 3.37 & 7.27 & 4.40 \\
\hline S. Ed. ( \pm$)$ & 0.64 & 0.667 & 2.818 & 6.74 & 0.32 & 0.44 & 2.26 & 0.7 \\
\hline C.D. (5\%) & 1.28 & 1.337 & 5.652 & N/A & N/A & N/A & N/A & N/A \\
\hline
\end{tabular}




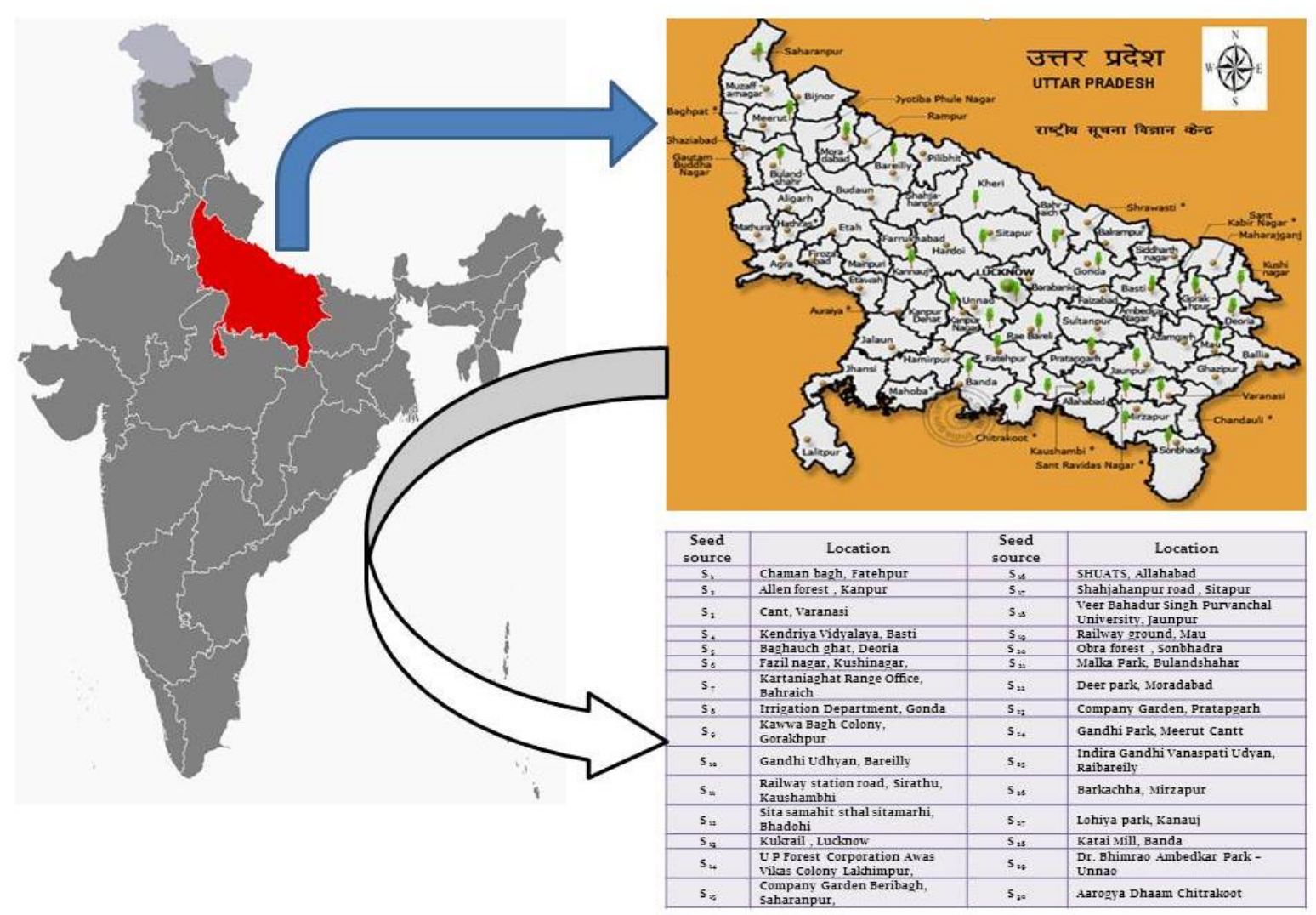

Fig.1 Seed source Terminalia arjuna genotypes collected from 30 sites of Uttar Pradesh

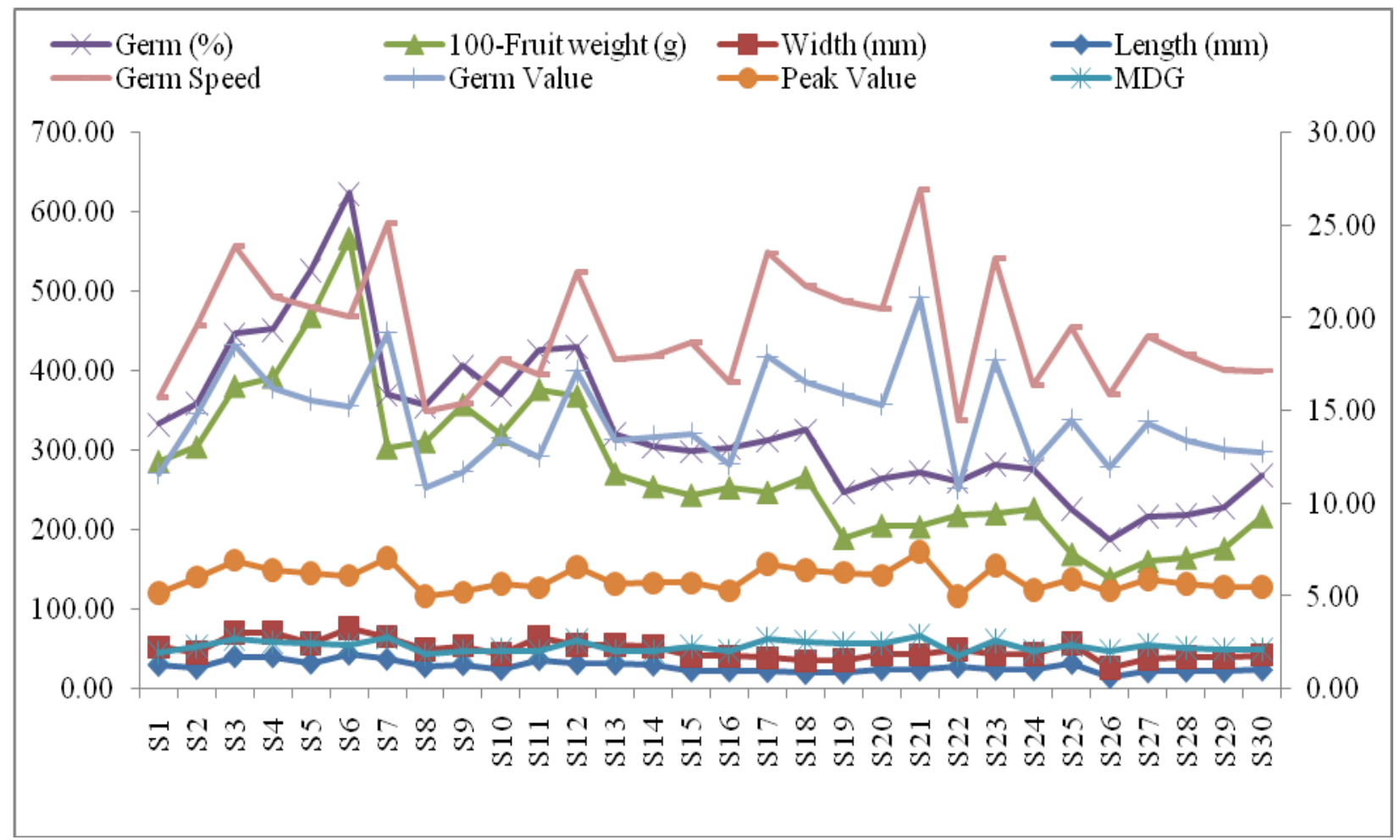

Fig.2 Seed size correlates with seedling emergence in Terminalia arjuna genotypes 
The observed effect of fruit size on seedling vigour and growth might be a direct result, because large seeds had more reserves in their cotyledons, but also an indirect result because large acorns germinated earlier, prolonging the growing season and thereby enhancing both below- and aboveground biomass gain, as well as the vertical growth of the resulting seedling (Tripathi and Khan, 1990; Ke and Werger Seiwa, 1999; 1998, 2000).

On the basis of earlier and the present studies, it is concluded that, higher germination percentages from large seeds is a stable character in $T$. arjuna. These findings suggest that the general assumption that seedling vigour has a fixed positive function of seed/fruit size needs to be reconsidered. There may be conflict in selection of an optimal seed size in some plant species.

Therefore, it is also suggested that, prior to sowing, the seeds should be screened. This practice will help in overcoming the inhibitory effect of adherent pulp on seed germination - and consequently on seedling establishment and ultimately on the production of quality stock.

The present study concludes that there is a slight difference between the large and medium size seeds where significance differences among medium to small seed. The large seeds were repeatedly performed to a higher germinability than the medium and small sizes. The increased germination rate could be related to the larger amount of reserves available in the large seed than in the medium or small seeds. The findings of experiment also suggest that seed vigor also differ in seed size in genotypes.

Hence, it is recommended to use only medium and large size seeds for growing, because they do result in higher germination behavior and seedling establishment.

\section{Acknowledgment}

The authors are grateful to the College of Forestry \& Environment, Sam Higginbottom University of Agriculture Technology and Sciences, (Formerly Allahabad Agriculture Institute), Allahabad, India for providing all necessary helps and facilities during the course of experiment and valuable comments of anonymous reviewers helped us a lot to improve this manuscript.

\section{References}

Agboola, D.A. E.O. Etejere, M.O. Fawole. 1993. Effect of orientation and soil types on germination of seeds of some tropical forest tree species, Seed Research, 21, pp. 13-20

Amri. E.M., 2010. Germination of Terminalia sericea Buch ex DC seeds: effect of temperature regime, photoperiod, gibberellic acid and potassium nitrate, American-Eurasian Journal of Agricultural and Environmental Sciences, 8, pp. 722-727

Dlamini, C.S., 2011. Provenance and family variation in seed mass and fruit composition in Sclerocarya birrea subspecies caffra, Journal of Horticulture and Forestry, 39, pp. 286-293

Geritz, S. A. H. 1998. Co-evolution of seed size and seed predation. Evol. Ecol. 12:891-911.

Hewitt, N. 1998. Seed size and shadetolerance: a comparative analysis of North America temperate trees. Oecologia 114:432-440.

Jakobsson, A. and O. Eriksson. 2000. A comparative study of seed number, seed size, seedling size and recruitment in grassland plants.

Jose, ' M. GO' MEZ, 2004, Bigger is not always better: conflicting selective pressures on seed size in quercus ilex, Evolution, 58(1), pp. 71-80 
Jurado, E. and M. Westoby. 1992. Seedling growth in relation to seed size among species of arid Australia. J. Ecol 80:407-416.

Ke, G., and M. J. A. Werger. 1999. Different responses to shade of evergreen and deciduous oak seedlings and the effect of acorn size. ActaOecologica 20:579586.

Khan, M.L., U. Shankar(2001)Effect of seed weight, light regime and substratum micro site on germination and seedling growth of Quercus semiserrata Roxb, Tropical Ecology, 42, pp. 117-125

Moles, A.T., D.S. Falster, M.R. Leishmann, M. Westoby., 2004. Small seeded species produce more seeds per square meter of canopy per year but not per individual per lifetime, Journal of Ecology, 92, pp. 384-396

Murali, K.S., 1997. Patterns of seed size, germination and seed viability of tropical tree species in southern India, Biotropica, 29, pp. 271-279

Negi, A.K.., N.P. Todaria, 1997.Effect of seed size and weight on germination pattern and seedling development of some multi-purpose tree species of Garhwal Himalaya, Indian Forester, 123, pp. 32-36

Purohit,V., J.S. Butola, C.P. Kuniyal, R.C. Su ndriyal, 2012. Seed pulp significantly inhibits seedling emergence in Terminalia bellerica, Current Science, 103, p. 764-764
Rathore, P., R. Suthar, S.D. Purohit. 2008. Micro propagation of Terminalia bellerica Roxb. From juvenile explants, Indian Journal of Biotechnology, 7, pp. 246-249

Schiotz, M., M.V. Boesen, J. Nabe-Nielsen, M. Sorensen, J. Kollmann. 2006. Regeneration in Terminalia oblonga (Combretaceae) - a common timber tree from a humid tropical forest (La Chonta, Bolivia), Forest Ecology and Management, 225, pp. 306-312

Shivanna, H., H.C. Balachandra, N.L. Suresh (2007), Effect of pre-sowing treatment on germination of Terminalia bellerica (Ber), Karnataka Journal of Agricultural Sciences, 20, pp. 442-443

Stevenson, P.R., M. Pineda, T. Samper 2005. Influence of seed size on dispersal pattern of woolly monkey (Lagothrix lagotricha) at Tinigua Park Colombia, Oikos, 110, pp. 435-440

Tripathi, R. S., and M. L. Khan. 1990. Effects of seed weight and microsite characteristics on germination and seedling fitness in two species of Quercus in a subtropical wet hill forest. Oikos 57:289-296.

Zhang, J. (1998) Variation and allometry of seed weight in Aeschynomene Americana, Annals of Botany, 82, pp. 843-847

Zobel, B. and Talbert. J., 1984. Applied forest tree improvement.

\section{How to cite this article:}

Hemant Kumar, S.B. Lal, A.M. Wani, Rajiv Umrao, Neelam Khare and Neeta Shweta Kerketta. 2017. Seed Size Correlates with Germination Traits in Terminalia Arjuna Genotypes. Int.J.Curr.Microbiol.App.Sci. 6(8): 2896-2903. doi: https://doi.org/10.20546/ijcmas.2017.608.346 